\title{
Illustrating the importance of particulate organic matter to pelagic microbial abundance and community structure-an Arctic case study
}

\author{
Lisa R. Hodges ${ }^{1,2}$, Nasreen Bano ${ }^{1}$, James T. Hollibaugh ${ }^{1}$, Patricia L. Yager ${ }^{1, *}$ \\ ${ }^{1}$ Department of Marine Sciences, University of Georgia, 220 Marine Sciences Building, Athens, Georgia 30602-3636, USA \\ ${ }^{2}$ Present address: Centers for Disease Control \& Prevention, 1600 Clifton Road, Mail-Stop C16, Atlanta, Georgia 30333, USA
}

\begin{abstract}
The pelagic bacterial community composition of the summertime Chukchi Sea (coastal Alaskan Arctic) was investigated under varying particle concentrations. Free-living and wholecommunity assemblages were compared using PCR-amplified 16S rDNA with denaturing gradient gel electrophoresis (PCR/DGGE) alongside traditional geochemical and microbial inventories. Algal blooms were characterized by increased microbial abundance, decreased species richness, and decreased similarity between free-living and whole-community bacterial assemblages. Bacterial and viral abundance correlated positively with a bloom index identified by principle components analysis that included particulate organic carbon and nitrogen, total organic carbon, and chlorophyll $a$, but not dissolved organic carbon or inorganic nutrients. The species richness of the free-living community correlated negatively with microbial abundance; differences between free-living and wholecommunity assemblages correlated positively with viral abundance. Algal blooms may therefore increase microbial abundance while stimulating a succession of the bacterial assemblage to fewer free-living species and more specialized particle-associated bacteria. Such community-level shifts are very likely to impact the fate of carbon in high production and export regions like the coastal Arctic. We speculate about the importance of viral lysis to such a succession.
\end{abstract}

KEY WORDS: Bacterioplankton · Virioplankton · Bacterial community composition · Particleassociated bacteria · Free-living bacteria · Psychrophiles · Arctic · Carbon fluxes

Resale or republication not permitted without written consent of the publisher

\section{INTRODUCTION}

Bacterioplankton and virioplankton are known to be important components of polar aquatic communities. Substantial microbial activity is found in summertime Arctic waters (e.g. Cota et al. 1996, Steward et al. 1996, Wheeler et al. 1996), where intense algal blooms form in areas of open water, such as leads and polynyas (Middelboe et al. 2002), and under sea-ice (Maranger et al. 1994). Significant increases in bacterial and viral abundance, bacterial activity, and changes in bacterial community composition are observed coincident with algal blooms in the summertime Chukchi Sea (Yager et al. 2001), where the highest values of bacterial biomass and production in the Arctic Ocean are reported (Rich et al. 1997).
Although the mechanisms involved are uncertain, large spatial variations in bacterial community composition are observed in Arctic waters (Ferrari \& Hollibaugh 1999, Bano \& Hollibaugh 2000, 2002). Shifts in dominant bacterial species can occur seasonally (Pinhassi \& Hagström 2000) or during marine algal blooms (Castberg et al. 2001, Fandino et al. 2001, Yager et al. 2001). In non-Arctic environments, the richness of the bacterioplankton assemblage, defined as the number of bands resolved by PCR/DGGE, may decline over a season (Hollibaugh et al. 2000) or during a phytoplankton bloom (Castberg et al. 2001). Changes in bacterial community composition, marked by phylotype-specific mortality and the emergence of new phylotypes, are found during mesocosm phytoplankton blooms (Reimann et al. 2000, Castberg et al. 2001). Substrate 
concentration, bacterivory, and bacteriophage are also likely to impact bacterial community composition since they affect bacterial abundance and activity.

In a variety of aquatic systems, free-living bacterial assemblages differ from those that are particleassociated (Delong et al. 1993, Acinas et al. 1999, Crump et al. 1999, Fandino et al. 2001, Riemann \& Winding 2001). Free-living assemblages are often more diverse than particle-associated assemblages and their species richness can change with depth and trophic conditions (Acinas et al. 1999, Hollibaugh et al. 2000, Long \& Azam 2001). New particle-associated phylotypes appear in the $>1.0 \mu \mathrm{m}$ size fraction during peaks in phytoplankton blooms when bacterial production and enzyme activities are greater (Riemann et al. 2000). In marine environments, particle-associated bacteria can be responsible for more than half of total bacterial production (Crump et al. 1998, Lee et al. 2001) and particulate organic matter (POM) degradation (Becquevort et al. 1998, Turley \& Stutt 2000). During the dense algal blooms of the Arctic summer, particle-associated bacteria are likely to become important agents of POM degradation (Huston \& Deming 2002) and may trigger bacterial community succession (Wells \& Deming 2003).

To investigate the potential mechanisms behind bacterial community succession in the coastal pelagic Arctic, we examined differences in bacterial community composition between free-living and wholecommunity assemblages, bacterial and viral abundance, along with a suite of biogeochemical variables (chlorophyll $a$, nutrients, and total, particulate and dissolved organic carbon and nitrogen), in the Chukchi Sea (see Fig. 1) during late summer. We compared high versus low POM regions to test the hypothesis that increased organic matter concentrations and viral infection are important determinants of bacterial abundance and community composition in these Arctic waters. Principle components and correlation analyses were used to determine the most significant factors explaining variation in bacterial community composition and differences between free-living and wholecommunity assemblages.

\section{MATERIALS AND METHODS}

Sampling. Seawater samples were collected from the Chukchi Sea aboard the USCGC 'Polar Star' (Arctic West Science of Opportunity Cruise; August 2000) using a standard CTD rosette equipped with twelve 301 Niskin bottles. The icebreaker would either sample through an existing opening in the ice, or make an opening large enough to sample through. We chose 5 stations (Fig. 1, see also Table 1) to sample variable

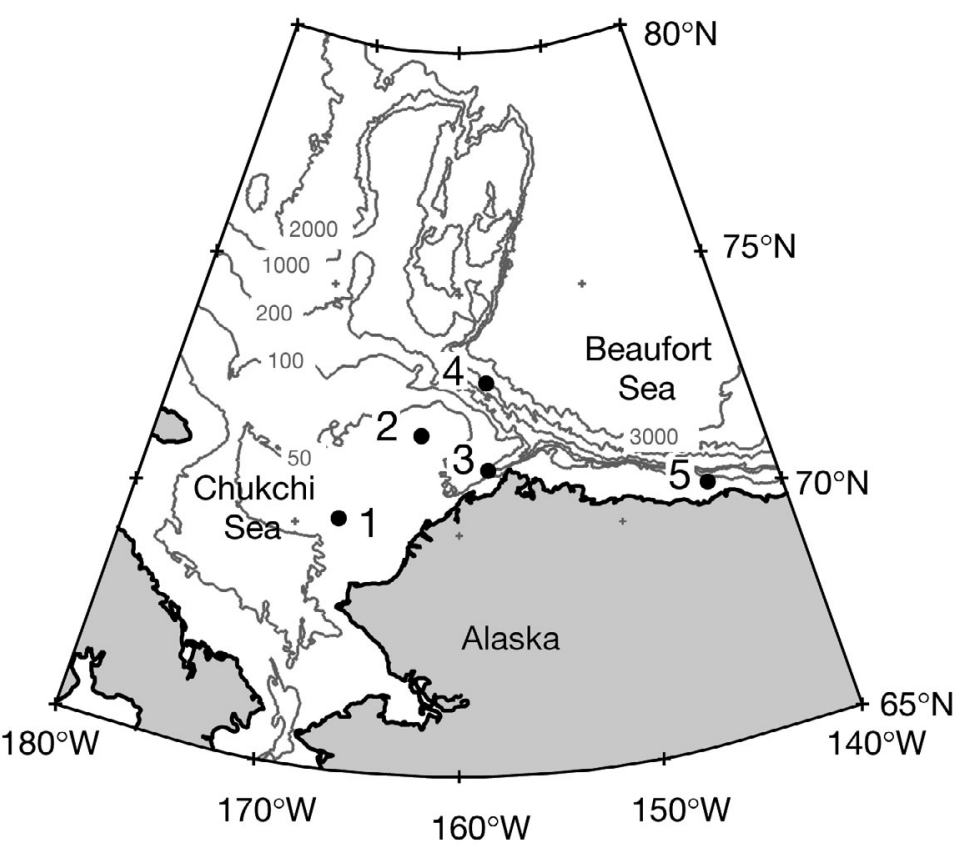

Fig. 1. Location of Stns 1 to 5 sampled in August 2000 in Arctic West Section (AWS00) aboard USCGC 'Polar Star'. Coastlines and bathymetry from IBCAO Version 1.0 (Jakobsson et al. 2000)

ice-cover and production regimes. Stns 1, 2, and 3 were on the Chukchi shelf with bottom depths of 45 , 42 , and $72 \mathrm{~m}$, respectively; Stn 4 was on the slope with a bottom depth of $2189 \mathrm{~m}_{i}$ Stn 5 was on the Beaufort shelf with a bottom depth of $145 \mathrm{~m}$. We selected 3 sampling depths according to light intensity (percentage of surface irradiance, $I_{0}$, as determined by Secchi disk depth): (1) $100 \% I_{0}$ (surface), (2) $30 \% I_{0}$ (typically the chlorophyll maximum), and (3) $1 \% I_{\mathrm{o}}$ (bottom of the photic zone).

Seawater chemistry. Duplicate seawater samples from separate Niskin bottles were analyzed for chlorophyll a (chl $a_{i}$ Holm-Hansen et al. 1965), dissolved organic carbon (DOC; Skoog et al. 1997), particulate organic carbon and nitrogen (POC and PON; Belicka 2002), nitrate and nitrite $\left(\mathrm{NO}_{3}{ }^{-}\right.$and $\mathrm{NO}_{2}{ }^{-}$; Strickland \& Parsons 1972), ammonium $\left(\mathrm{NH}_{4}{ }^{+} ;\right.$Solórzano 1969), and phosphate $\left(\mathrm{PO}_{4}{ }^{3-}\right.$; Strickland \& Parsons 1972). Total organic carbon (TOC) was calculated as the sum of DOC and POC values, and dissolved inorganic nitrogen (DIN) was the sum of $\mathrm{NO}_{3}{ }^{-}, \mathrm{NO}_{2}{ }^{-}$, and $\mathrm{NH}_{4}{ }^{+}$.

Bacterial and viral abundance. Duplicate seawater samples were collected at each depth from separate Niskin bottles and fixed with $0.2 \mu \mathrm{m}$ filtered formaldehyde ( $2 \%$ final concentration). Bacterial abundance (BACT) and virus-like particles (VLP) were enumerated by epifluorescence microscopy following staining with 4', 6-diamidino-2-phenylindole (DAPI, $20 \mu \mathrm{g} \mathrm{ml}^{-1}$; 
Sigma; Porter \& Feig 1980) and SYBR Gold $\left(2.5 x_{i}\right.$ Chen et al. 2001). Mean bacterial and viral counts were then used to calculate the mathematical product of bacterial and viral abundance, $\mathrm{VB}(\mathrm{VB}=\mathrm{BACT} \times \mathrm{VLP})$.

A Student's $t$-test (Sokal \& Rohlf 1995) was used to test for differences of means of measured chemical and microbial variables between high and low POM stations. Principle components analysis ( $\mathrm{PCA}_{\text {; Davis }}$ 2002) was performed to analyze the relationships between the environmental variables $\mathrm{chl} a_{1}$ TOC, DOC, $\mathrm{POC}, \mathrm{PON}, \mathrm{DIN}$, and $\mathrm{PO}_{4}{ }^{3-}$. Our goal was to produce a set of algal bloom indices against which we could compare microbial variables. PCA arranged the samples along orthogonal axes defined by linear combinations of these variables. PCA scores reflect the position of each sample along those axes. Pearson product-moment correlation coefficients $\left(\mathrm{R}_{x y}\right.$ i Sokal \& Rohlf 1995) were calculated between these scores and microbial variables.

Bacterial community composition. Two $10 \mathrm{l}$ seawater samples were collected from separate Niskin bottles for each sampling depth. The free-living community sample was prepared by gravity filtration from the Niskin through a very large diameter $(293 \mathrm{~mm})$ Nuclepore polycarbonate membrane $(3 \mu \mathrm{m}$ pore size) to avoid clogging (no changes in the rate of filtration were observed during processing). The whole-community sample was not prefiltered. Community DNA was collected from these samples by pressure filtration through a sterile $0.22 \mu \mathrm{m}$ Millipore Sterivex GV filter cartridge using a peristaltic pump. Excess water was expelled from the cartridge and $1.8 \mathrm{ml}$ of TES buffer (50 mM Tris- $\mathrm{HCl}, 40 \mathrm{mM}$ EDTA, $0.75 \mathrm{M}$ sucrose) was added. Cartridges were then frozen at $-80^{\circ} \mathrm{C}$ until analyzed by polymerase chain reaction/denaturing gradient gel electrophoresis (PCR/DGGE; Muyzer et al. 1993, Murray et al. 1996). Unfortunately, the cartridge from Stn 5 was accidentally thawed during a freezer failure before it could be processed.

Extraction and purification of DNA followed methods described elsewhere (Ferrari \& Hollibaugh 1999, Bano \& Hollibaugh 2000). Briefly, total community DNA lysate was obtained from the Sterivex units using lysozyme and Proteinase K treatments. DNA was purified from this lysate by sequential extraction with phenol/chloroform. The quantity and quality of purified DNA was assessed by electrophoresis of a portion of the extracts in a $1.5 \%$ agarose gel. Extracted DNA was amplified by PCR with the following primers: bacterial 356f with GC-clamp (CGC CCG CCG CGC CCC CGC CCC GTC CCG CCG CCC CCG CCC CCC TAC GGG AGG CAG CAG) and universal 517r labeled with fluorescein (5'-F ATT ACC GCG GCT GCT GG-3'). PCR products were precipitated with ethanol and quantified by the Hoechst dye assay (Paul \& Myers 1982).
Denaturing gradient gel electrophoresis was performed on a CBS Scientific DGGE System (Del Mar) on a $6.5 \%$ polyacrylamide gel containing a 45 to $65 \%$ gradient of denaturant (formamide and urea) according to methods described elsewhere (Ferrari \& Hollibaugh 1999, Bano \& Hollibaugh 2000). Wells were loaded with $24 \mu \mathrm{l}$ of sample consisting of $7 \mu \mathrm{g}$ of PCR product, $5 \mu \mathrm{l}$ TE buffer, and $12 \mu \mathrm{l}$ loading dye and run at $75 \mathrm{~V}$ for $15 \mathrm{~h}$. PCR/DGGE amplicons from Clostridium perfringens (Sigma) and Bacillus thuringiensis (Sigma) genomic DNA were combined to create a marker and positive control. DNA banding patterns were detected and recorded digitally using an FMBIO II unit and software (Hitachi). Because of our choice of primers, which result in short 16S rRNA fragments, it is possible for a single band to represent more than 1 species. In our experience, however, most bands from this region do not contain multiple species (4 out of 30 tested; Bano \& Hollibaugh 2002).

Gel images were processed and analyzed with Molecular Analyst-Fingerprint Plus software (BioRad Version 1.12). Phylotypes, defined as bands that were recognized by the software, were noted and counted for each sample lane. Bands in each sample were scored present or absent at each position. Species richness was determined as the number of bands resolved by PCR/DGGE in 1 sample lane. The 54 bands in the 22 samples and 4 standards were ordinated with nonmetric multidimensional scaling (MDS), using the software package PC-ORD (McCune \& Mefford 1999). Prior to analysis, 6 bands were removed from the data set because they occurred in only 1 sample and would not aid in ordination. The MDS used the Sorenson similarity coefficient, was constrained to a 2-dimensional solution, and was run from 500 randomized starts to avoid local minima. The run with the lowest value of stress among these randomized starts was selected for analysis. The MDS distances between free-living and whole-community samples, which were calculated geometrically from Axis 1 and Axis 2 scores, determined dissimilarity. Significance in the difference of these distances, between high POM and low POM stations, was assessed by a $t$-test (Sokal \& Rohlf 1995). Cluster analysis (Dice/UPGMA) was used to generate a dendrogram of the similarity of banding patterns between lanes (samples) as described elsewhere (Ferrari \& Hollibaugh 1999).

\section{RESULTS}

\section{Algal bloom indices}

Physical conditions in the summertime Arctic varied over a relatively small range (Table 1) and did not gen- 
Table 1. Station information with physical variables. Dates given as mm/dd/yr

\begin{tabular}{|cccccccc|}
\hline Stn & $\begin{array}{c}\text { Sampling } \\
\text { date }\end{array}$ & $\begin{array}{c}\text { Latitude } \\
\left({ }^{\circ} \mathrm{N}\right)\end{array}$ & $\begin{array}{c}\text { Longitude } \\
\left({ }^{\circ} \mathrm{W}\right)\end{array}$ & $\begin{array}{c}\text { Ice cover } \\
(\%)\end{array}$ & $\begin{array}{r}\text { Secchi } \\
\text { depth }(\mathrm{m})\end{array}$ & $\begin{array}{c}\text { Surface } \\
T\left({ }^{\circ} \mathrm{C}\right)\end{array}$ & $\begin{array}{c}\text { Bottom } \\
\text { depth }(\mathrm{m})\end{array}$ \\
\hline 1 & $08 / 07 / 00$ & 70.19 & 167.35 & 70 & 10 & -1.15 & 45 \\
2 & $08 / 09 / 00$ & 70.04 & 162.50 & $10-50$ & 5.5 & -0.77 & 42 \\
3 & $08 / 12 / 00$ & 71.33 & 158.06 & 90 & 6.2 & -1.3 & 72 \\
4 & $08 / 14 / 00$ & 73.14 & 158.03 & 90 & 29 & -1.16 & 2189 \\
5 & $08 / 18 / 00$ & 70.39 & 144.37 & 80 & 14 & 0.06 & 145 \\
\hline
\end{tabular}

(20 m) (Table 2). DOC concentrations did not differ significantly between high and low POM stations $(\mathrm{p}=0.60)$, and were constant with depth except at Stn 1 where they matched the chlorophyll a profile (Table 2). DIN and $\mathrm{PO}_{4}{ }^{3-}$ were typically reduced in surface waters at all stations and increased with increasing depth (Table 2).

Nutrient concentrations in the near-

erally provide much explanation for the observed biological variability. Surface water temperature ranged from -1.3 to $+0.06^{\circ} \mathrm{C}$ and ice cover generally increased northward (Table 1). Secchi depths were shallowest at Stns 2 and 3 (Table 1); Stns 2 and 3 also had significantly higher chl a $(\mathrm{p}=0.02)$, TOC $(\mathrm{p}=0.01)$, and POM ( $<<0.01$ ) concentrations than Stns 1, 4, and 5 (Table 2). Stns were grouped into high POM and low POM stations accordingly (Table 2). POM decreased with increasing depth at high POM stations, but tended to be uniform or increase with depth at low POM stations. Large chl a maxima were observed near the surface at Stn $2(4 \mathrm{~m})$ and at greater depths at Stns $3(16 \mathrm{~m})$ and 1 surface waters of high POM stations tended to be higher (although not as high as in deeper water), suggesting an ongoing bloom (sensu Yager et al. 2001) that had not yet depleted surface nutrients. Low POM stations tended to have low chlorophyll, but also showed depleted nutrient concentrations to greater depths, suggesting that a bloom had already taken place (rather than a pre-bloom condition). The chlorophyll concentration at Stn 1 was greatest at depth, suggesting that the bloom had sunk. Stn 1 therefore seems to represent an intermediate station between the high POM bloom Stns 2 and 3, and the low POM post bloom Stns 4 and 5.

Table 2. Mean values of station data comprising: sampling depth, chlorophyll a (chl a), dissolved inorganic nitrogen (DIN), phosphate $\left(\mathrm{PO}_{4}{ }^{3-}\right)$, dissolved (DOC) and particulate $(\mathrm{POC})$ organic carbon $(\mathrm{TOC}=\mathrm{DOC}+\mathrm{POC})$, particulate organic nitrogen $(\mathrm{PON})$, and bacterial (BACT) and viral (VLP) abundance. Bold values for Students' $t$-test indicate significant differences $(\alpha=0.05)$ between high and low POM stations

\begin{tabular}{|c|c|c|c|c|c|c|c|c|c|c|}
\hline Stn & $\begin{array}{c}\text { Depth } \\
\text { (m) }\end{array}$ & $\begin{array}{c}\mathrm{Chl} \mathrm{a} \\
\left(\mathrm{mg} \mathrm{m}^{-3}\right)\end{array}$ & $\begin{array}{l}\text { DIN } \\
(\mu \mathrm{M})\end{array}$ & $\begin{array}{c}\mathrm{PO}_{4}{ }^{3-} \\
(\mu \mathrm{M})\end{array}$ & $\begin{array}{l}\text { TOC } \\
(\mu \mathrm{M})\end{array}$ & $\begin{array}{l}\text { DOC } \\
(\mu \mathrm{M})\end{array}$ & $\begin{array}{l}\text { POC } \\
(\mu M)\end{array}$ & $\begin{array}{l}\text { PON } \\
(\mu M)\end{array}$ & $\begin{array}{c}\text { BACT } \\
\left(\times 10^{5} \mathrm{ml}^{-1}\right)\end{array}$ & $\begin{array}{c}\text { VLP } \\
\left(\times 10^{6} \mathrm{ml}^{-1}\right)\end{array}$ \\
\hline \multicolumn{11}{|c|}{ High POM stations } \\
\hline \multirow[t]{3}{*}{2} & 0 & 15.56 & 0.2 & 1.0 & 153 & 82 & 70.5 & 10.9 & 6.9 & 1.7 \\
\hline & 4 & 18.51 & 2.3 & 1.1 & 140 & 74 & 66.3 & 10.9 & 7.5 & 1.2 \\
\hline & 15 & 6.79 & 18.6 & 1.8 & 94 & 59 & 34.9 & 6.6 & 5.4 & 1.2 \\
\hline \multirow[t]{3}{*}{3} & 0 & 3.06 & 1.0 & 0.7 & 117 & 79 & 37.5 & 6.4 & 7.5 & 1.4 \\
\hline & 4 & 3.32 & 1.3 & 1.1 & 119 & 86 & 33.3 & 5.8 & 7.8 & 1.6 \\
\hline & 16 & 7.25 & 7.4 & 3.5 & 108 & 78 & 29.6 & 5.1 & 8.5 & 1.4 \\
\hline \multicolumn{2}{|c|}{ Mean } & 9.08 & 5.1 & 1.5 & 122 & 76 & 45.4 & 7.6 & 7.3 & 1.4 \\
\hline \multicolumn{2}{|c|}{ Variance } & 41.79 & 50.3 & 1.1 & 460 & 88 & 327.3 & 6.8 & 1.1 & 0.1 \\
\hline \multicolumn{11}{|c|}{ Low POM stations } \\
\hline \multirow[t]{3}{*}{1} & 0 & 0.54 & 0.1 & 0.2 & 63 & 48 & 14.8 & 2.1 & 4.5 & 1.7 \\
\hline & 5 & 0.85 & 0.1 & 0.6 & 87 & 72 & 15.2 & 2.5 & 8.7 & 0.8 \\
\hline & 20 & 2.24 & 2.1 & 0.9 & 154 & 138 & 16.2 & 2.7 & 7.8 & 1.3 \\
\hline \multirow[t]{3}{*}{4} & 0 & 0.07 & 0.6 & 0.6 & 60 & 58 & 1.8 & 0.3 & 0.9 & 0.1 \\
\hline & 21 & 0.13 & 0.4 & 0.7 & 60 & 58 & 2.4 & 0.3 & 1.4 & 0.2 \\
\hline & 81 & 0.07 & 14.1 & 1.6 & 57 & 56 & 1.4 & 0.2 & 0.8 & 0.2 \\
\hline \multirow[t]{3}{*}{5} & 0 & 0.22 & 0.7 & 0.6 & 89 & 84 & 5.5 & 1.0 & 1.9 & 0.1 \\
\hline & 11 & 0.17 & 1.1 & 0.7 & 76 & 71 & 5.1 & 0.8 & 1.8 & 0.2 \\
\hline & 41 & 0.15 & 4.4 & 1.6 & 73 & 57 & 16.2 & 1.8 & 1.8 & 0.4 \\
\hline \multicolumn{2}{|c|}{ Mean } & 0.49 & 2.6 & 0.8 & 80 & 71 & 8.7 & 1.3 & 3.3 & 0.6 \\
\hline \multicolumn{2}{|c|}{ Variance } & 0.50 & 20.3 & 0.2 & 913 & 743 & 44.3 & 1.0 & 9.2 & 0.3 \\
\hline \multicolumn{11}{|c|}{ Student's $t$-test: 2 -sample test assuming unequal variances } \\
\hline \multicolumn{2}{|c|}{$\mathrm{p}(\mathrm{T} \leq t) 2$-tail } & 0.02 & 0.4 & 0.2 & 0.01 & 0.6 & 0.003 & 0.001 & 0.004 & 0.002 \\
\hline
\end{tabular}


Principle components analysis (PCA) arranged samples along orthogonal axes. The first 3 axes combined to explain a total of $94 \%$ of sample variance: (1) On $\mathrm{PCA}_{1}, \mathrm{POC}, \mathrm{PON}, \mathrm{chl} a$, and TOC combined to explain $54 \%$ of sample variance with component loadings or Rvalues of $0.957,0.960,0.925$, and 0.907, respectively; (2) on $\mathrm{PCA}_{2}$, DIN and $\mathrm{PO}_{4}{ }^{3-}$ combined to explain $25 \%$ of sample variance with R-values of 0.876 and 0.771 , respectively; (3) on $\mathrm{PCA}_{3}$, DOC explained $15 \%$ of sample variance with an R-value of 0.734 . $\mathrm{PCA}_{1}$, therefore, represents the primary algal bloom index, reflecting the large increase in autotrophic biomass; $\mathrm{PCA}_{2}$ reflects the decrease of inorganic nutrients during the bloom; $\mathrm{PCA}_{3}$ represents a change in DOM during the bloom that occurred independent of the increase in biomass. Physical variables, when included in the PCA, provided no additional information; the first 3 axes were the same and variables such as depth, water temperature and latitude gave component loadings less than 0.70 . The only exception was that light depth was a negative correlate $(-0.719)$ of the inorganic nutrient axis.

\section{Bacterial and viral abundance}

Values for bacterial abundance ranged from 0.8 to $8.7 \times 10^{5} \mathrm{ml}^{-1}$ (Table 2). Values for VLP (0.1 to $1.7 \times$ $10^{6} \mathrm{ml}^{-1}$ ) were typically an order of magnitude higher than for bacteria, but correlated significantly $(R=0.824$; Table 3). Both bacterial abundance and VLP were significantly higher at high POM stations $(p=0.004$ and 0.002 , respectively); bacterial abundance and VLP values were also higher at Stn 1 than at Stns 4 and 5 (Table 2).

The mathematical product of bacterial abundance times VLP (VB) ranged over 2 orders of magnitude from $10^{10}$ to $10^{12} \mathrm{ml}^{-1}$ and was significantly higher at high POM stations $(p=0.002)$. Since the lytic infection of bacteria depends on their encounter rate with viruses, it therefore depends on the combined abundance of both populations. The theoretical lytic threshold, the point at which the concentration of bacteria and viruses is high enough to support bacterial lysis (VB $=10^{12} \mathrm{ml}^{-1}$; Wilcox \& Fuhrman 1994), was reached at all depths at Stn 3, the surface at Stn 2, and at 1\% $I_{\text {o }}$ at Stn 1 (Fig. 2). Values for VB at other depths at Stns 1 and 2 were slightly below the lytic threshold, while those at Stns 4 and 5 were considerably lower (Fig. 2). The VB values at Stn 1 seemed to cluster with those for Stns 2 and 3, perhaps related to its more intermediate bloom status compared to the clearly post-bloom Stns 4 and 5 .

Bacterial abundance, VLP, and VB were significantly correlated to the sample scores produced by $\mathrm{PCA}_{1}$, but not to those of the other axes $\left(\mathrm{PCA}_{2}, \mathrm{PCA}_{3}\right.$ Table 3$)$.

\section{Bacterial community composition}

Bacterial community composition and richness differed between stations and POM regimes. Samples from the same station generally resembled each other more than samples from different stations at the same depth or light level, and low POM stations generally resembled each other more than high POM stations (Figs. 3 \& 4). Stn 2 clustered closer to the low POM stations than Stn 3, perhaps indicating that Stn 3 was earliest in the bloom progression. The number of bands, or species richness, identified in both whole community and free-living samples was greater at low POM stations; the number of bands common to both free-living and whole-community assemblages was also higher at

Table 3. Correlation table showing Pearson product-moment correlation coefficients (R) between bacterial community variables and principle components analysis (PCA) axes, showing 3 axes $\left(\mathrm{PCA}_{1}, \mathrm{PCA}_{2}\right.$ and $\left.\mathrm{PCA}_{3}\right)$ with percent variance explained and their principle components. Correlation coefficients were calculated between PCA scores generated for sample and bacterial abundance (BACT), viral abundance (VLP), mathematical product of viral and bacterial abundance (VB), species richness (no. of bands) of each assemblage, and dissimilarity between whole-community (FLPA) and free-living (FL) assemblages (MDS distance). Correlation coefficients were also calculated for these same variables with bacterial and viral abundance. Bold indicates significant at $\alpha=0.05 ;{ }^{*}$ Significance at $\alpha=0.01 ;{ }^{*} \mathrm{PCA}_{1} \mathrm{R}$ values for these variables are POC $=0.96$, PON $=0.96$, chl $a=0.93$, TOC $=0.91$

\begin{tabular}{|c|c|c|c|c|c|c|c|}
\hline & $\mathrm{n}$ & $\begin{array}{c}\mathrm{PCA}_{1}=54 \% \\
(\mathrm{POC}, \mathrm{PON}, \text { chl } a, \mathrm{TOC})^{* *}\end{array}$ & $\begin{array}{l}\mathrm{PCA}_{2}=25 \% \\
\left(\mathrm{DIN}, \mathrm{PO}_{4}{ }^{3-} \text { ) }\right.\end{array}$ & $\begin{array}{l}\mathrm{PCA}_{3}=15 \% \\
\text { (DOC) }\end{array}$ & $\mathrm{BACT}$ & VLP & VB \\
\hline BACT & 15 & $0.731^{*}$ & -0.130 & 0.204 & - & $0.824^{*}$ & - \\
\hline VLP & 15 & $0.706^{*}$ & -0.066 & -0.020 & $0.824^{*}$ & - & - \\
\hline VB & 15 & $0.778^{*}$ & -0.115 & 0.134 & - & - & - \\
\hline No. of bands (FLPA) & 10 & -0.381 & -0.512 & 0.150 & -0.434 & -0.280 & -0.396 \\
\hline No. of bands (FL) & 12 & -0.453 & -0.160 & 0.218 & -0.620 & -0.588 & -0.653 \\
\hline No. common bands & 10 & -0.453 & -0.357 & 0.270 & -0.539 & -0.533 & -0.561 \\
\hline MDS Distance & 10 & 0.368 & 0.288 & -0.132 & 0.365 & $0.704^{*}$ & 0.533 \\
\hline
\end{tabular}




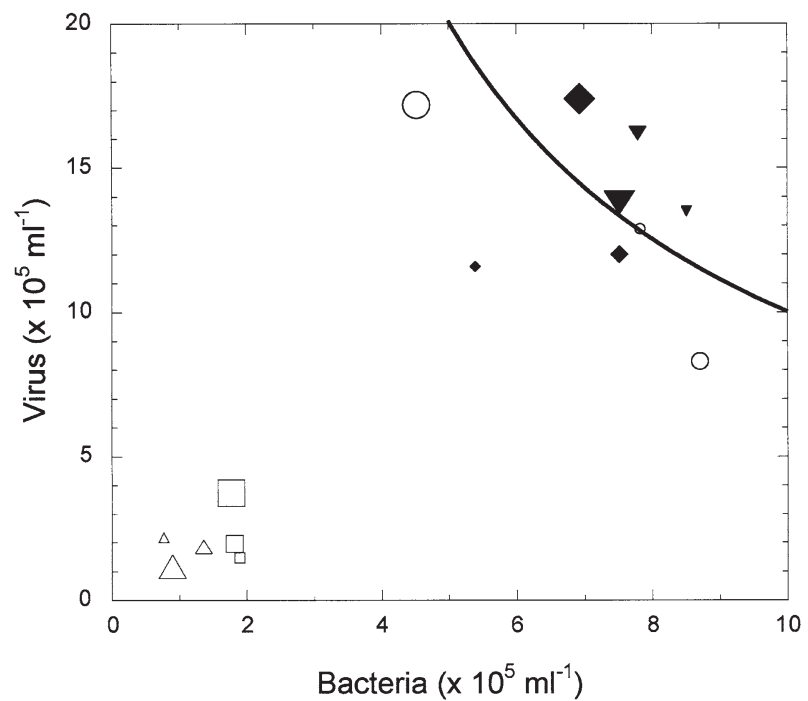

Fig. 2. Mean bacterial versus viral abundance for at Stns 1 to 5. Open symbols: low POM, filled symbols: high POM stations; increasing depth indicated by decreasing symbol size. (O) Stn 1; $\bullet \operatorname{Stn} 2 ;(\mathbf{\nabla}) \operatorname{Stn} 3 ;(\Delta) \operatorname{Stn} 4 ;(\square) \operatorname{Stn} 5$. Curve represents theoretical lytic threshold (viral $\times$ bacterial abundance $=10^{12} \mathrm{ml}^{-1}$ ); data points above curve represent samples with combined abundance great enough to support encounter rates high enough for significant lysis (Wilcox \& Fuhrman 1994). Correlation between viral and bacterial abundance is also apparent $(R=0.908, n=15)$

these stations ( $p<0.01$; Table 4$)$. The MDS distance, a measure of dissimilarity, between free-living and whole-community assemblages from a given depth and station was significantly greater at high POM stations ( $p=0.04$; Table 4, Fig. 3); at low POM stations, the whole communities did not differ as much from the free-living communities.

No significant correlation existed between either species richness or dissimilarity and any PCA axis (Table 3). Consistent with the $t$-tests, however, richness and similarity tended to trend negatively with POM. PCA 2 (DIN, $\mathrm{PO}_{4}{ }^{3-}$ ) and $\mathrm{PCA}_{3}$ (DOC) axes were not significantly correlated to any other variable (Table 3). The number of bands found in the free-living assemblage did correlate negatively with microbial abundance (bacterial abundance, VLP, and VB; $\mathrm{p}<$ 0.05 ) and MDS distance correlated significantly with VLP ( $\mathrm{p}<0.01$; Table 3$)$.

\section{DISCUSSION}

\section{Arctic algal blooms}

High POM concentrations are associated with high primary production since POM is often strongly correlated with chl $a$ in Arctic seas (Guo et al. 2004, Wang et

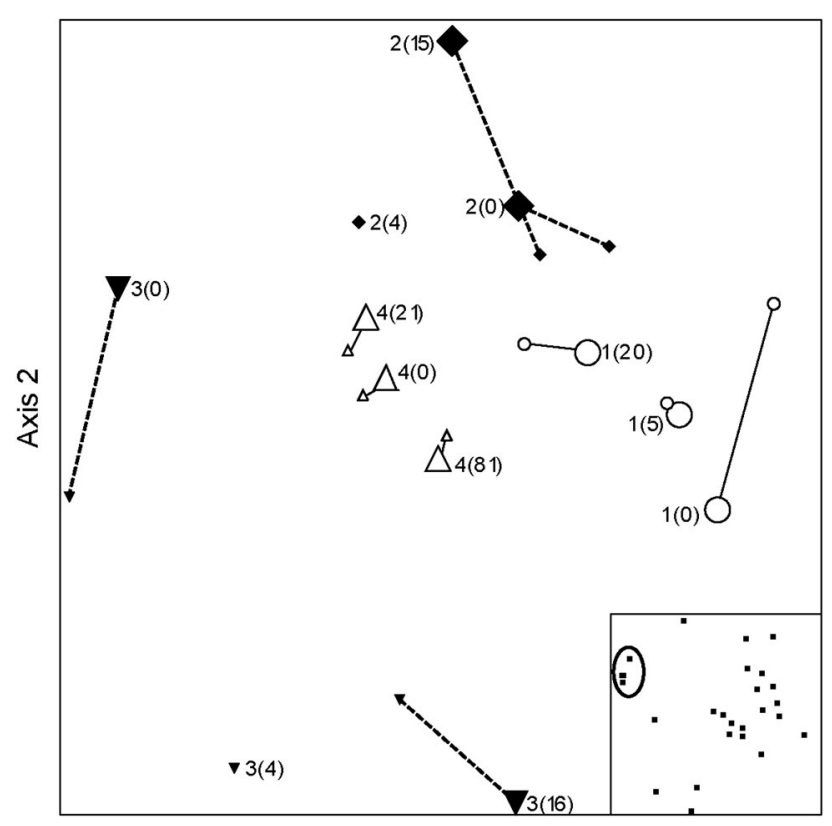

Axis 1

Fig. 3. Plot of sample scores from multidimensional scaling analysis of DGGE banding patterns for whole community (large symbols) and free-living (small symbols) assemblages. Station symbols as in Fig. 2. Lines connect pairs (identified by station number and depth in parentheses); dashed lines: high POM, continuous lines: low POM stations. Final stress was 20.40445, with an instability of 0.02621 . Inset: run including standard controls (encircled), which clustered well when included in analysis

al. 2005). In contrast, DOC concentrations do not correlate well with other bloom indices, either because production mechanisms (e.g. Jumars et al. 1989) are slow or bacterial uptake is rapid (e.g. Yager \& Deming 1999, Yager et al. 2001). Particles are an important source of organic matter to bacterioplankton in Arctic seas during summertime production (Ritzrau 1997, Yager et al. 2001). Increased particle-associated activity, depletion of nitrogen in POM, and increased extracellular protease activity observed in a summertime Arctic polynya suggests that particle-associated bacteria respond to POM at this time (Vetter \& Deming 1994, Huston \& Deming 2002). Particle-associated bacteria may therefore be responsible for observable changes in bacterial abundance and community composition during times of high particle production in summertime Arctic seas.

\section{Bacterial and viral abundance}

Increased substrate availability may explain the elevated values of bacterial abundance and VLP at 

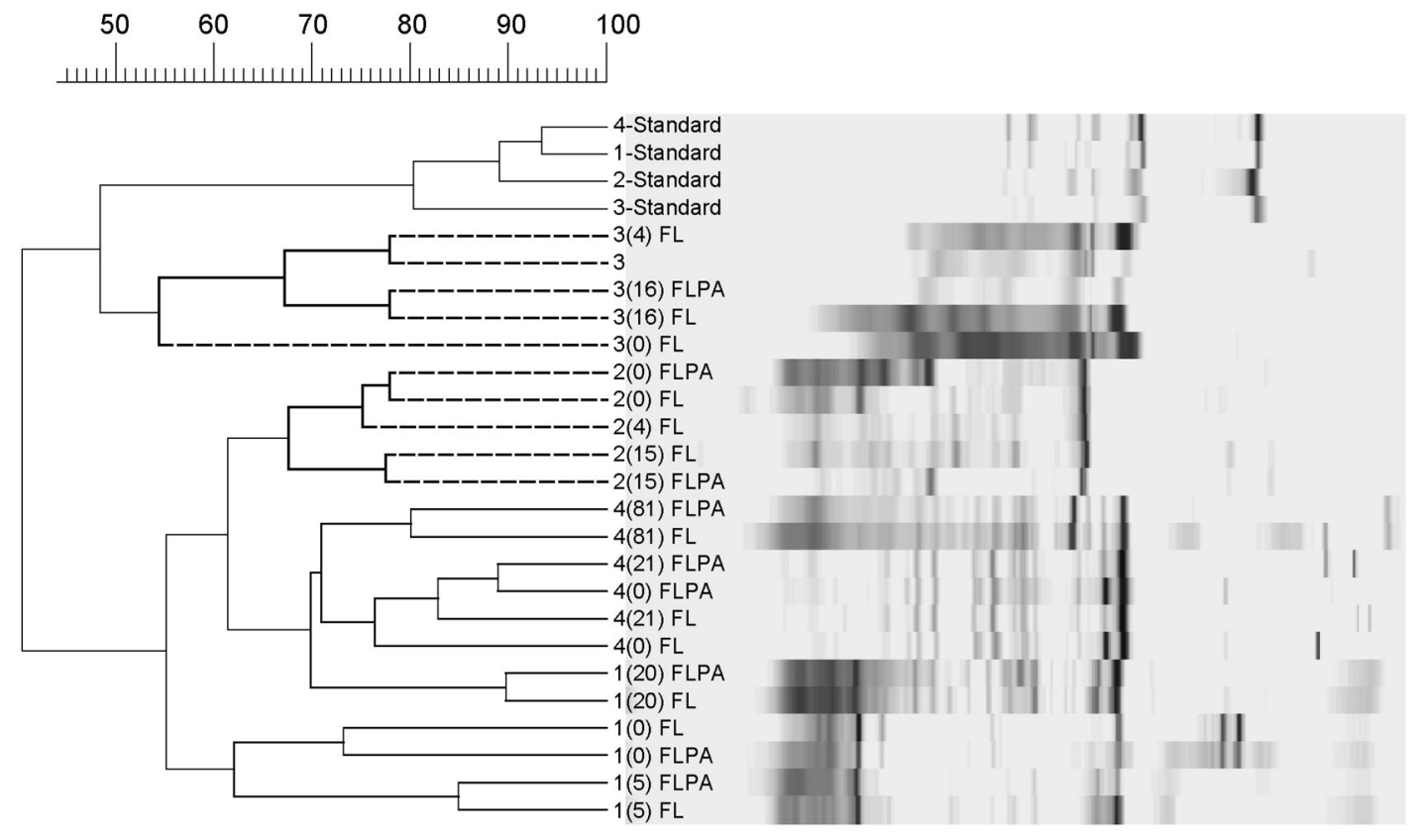

Fig. 4. Similarity dendrogram created by standardizing 4 DGGE gels containing samples from Stns 1 to 4 . Scale: percent similarity of banding patterns derived from cluster analysis. Samples labeled with station number (1 to 4), sampling depth ( $\mathrm{m}$; in parentheses), and source, i.e. free-living (FL) or whole-community (FLPA) assemblages. Dashed lines: high POM stations

Table 4. Bacterial community composition of whole-community (FLPA) and free-living (FL) assemblages at high and low POM stations shown as species richness (number of bands in PCR/DGGE fingerprints), number of bands common to both assemblages, and dissimilarity of whole community and freeliving DGGE fingerprints as distance between pairs in MDS. Bold $p$ values at base of each column represent significant differences between samples from low and high POM stations. nd: not determined

\begin{tabular}{|c|c|c|c|c|c|}
\hline \multirow[t]{2}{*}{ Stn } & \multirow{2}{*}{$\begin{array}{l}\text { Depth } \\
\text { (m) }\end{array}$} & \multicolumn{2}{|c|}{ No. of bands } & \multirow{2}{*}{$\begin{array}{l}\text { Common } \\
\text { bands }\end{array}$} & \multirow{2}{*}{$\begin{array}{c}\text { MDS } \\
\text { distance }\end{array}$} \\
\hline & & FLPA & FL & & \\
\hline \multicolumn{6}{|c|}{ High POM } \\
\hline \multirow[t]{3}{*}{2} & 0 & 17 & 18 & 11 & 0.39 \\
\hline & 4 & nd & 14 & nd & nd \\
\hline & 15 & 14 & 16 & 9 & 0.91 \\
\hline \multirow[t]{3}{*}{3} & 0 & 10 & 12 & 5 & 0.84 \\
\hline & 4 & nd & 8 & nd & nd \\
\hline & 16 & 8 & 10 & 5 & 0.61 \\
\hline $\mathrm{Me}$ & & 12 & 13 & 7.5 & 0.69 \\
\hline Var & & 16 & 14 & 9.0 & 0.06 \\
\hline \multicolumn{6}{|c|}{ Low POM } \\
\hline \multirow[t]{3}{*}{1} & 0 & 23 & 18 & 13 & 0.84 \\
\hline & 5 & 16 & 17 & 12 & 0.06 \\
\hline & 20 & 30 & 28 & 24 & 0.26 \\
\hline \multirow[t]{3}{*}{4} & 0 & 23 & 25 & 20 & 0.10 \\
\hline & 21 & 22 & 21 & 17 & 0.13 \\
\hline & 81 & 21 & 27 & 20 & 0.09 \\
\hline $\mathrm{Me}$ & & 23 & 23 & 18 & 0.24 \\
\hline Var & & 20 & 22 & 21 & 0.09 \\
\hline \multicolumn{6}{|c|}{ Student's $t$-test: 2 -sample assuming equal variances } \\
\hline $\mathrm{p}(\mathrm{T}$ & -tail) & 0.006 & 0.003 & 0.005 & 0.04 \\
\hline
\end{tabular}

high POM stations. Although particle-associated bacteria cannot consume POM directly, they may be able to solubilize POM using cell-attached or cellfree extracellular enzymes (Smith et al. 1992, Vetter et al. 1998). Values for BACT, VLP, and VB were strongly correlated with the $\mathrm{PCA}_{1}$ axis (POM/chl $a_{\text {; }}$ Table 2). Bacterial abundance often correlates with chl a (Cole et al. 1988, Poremba et al. 1999) and POM (Kimura et al. 2001). In contrast to other studies, we observed no significant correlation between bacterial abundance and VLP with inorganic nutrients (Hagström et al. 2001) or DOM (Carlson \& Ducklow 1996).

Although the dynamics of bacteria and VLP can be temporally decoupled (Hennes \& Simon 1995), we found no evidence for control of bacterial abundance by viruses. An increase in VLP did not correspond to a decrease in bacterial abundance, as found in other studies in the summertime Chukchi Sea (Steward et al. 1996, Yager et al. 2001). The strong, positive BACTVLP correlation we observed, as reported in other studies (Cochlan et al. 1993, Maranger \& Bird 1995, Middelboe et al. 2002), suggests that viruses are bacteriophages (Wommack et al. 1992, Fuhrman 1999) with high production rates (Noble \& Fuhrman 2000). The strong positive correlation observed between VLP and the $\mathrm{PCA}_{1}$ axis suggests that POM may indirectly influence VLP, probably by increasing the abundance of bacterial hosts. 


\section{Bacterial community composition}

Bacterial community succession and decreased richness is common during phytoplankton blooms (Riemann et al. 2000, Riemann \& Winding 2001, Yager et al. 2001). The decreased richness we observed at high POM stations may be partially explained by the availability of particles produced by episodic blooms of phytoplankton or ice algae. As in other aquatic environments (Delong et al. 1993, Acinas et al. 1999, Fandino et al. 2001), we found that free-living and whole-community bacterial assemblages were different in high primary production/POM stations in the Chukchi Sea. Unique particle-associated bacterial species often appear at times of high primary production in response to particles (Hollibaugh et al. 2000, Riemann \& Winding 2001). Decreased similarity between banding patterns of free-living and whole-community assemblages at high POM suggests that POM itself may be responsible for changes in bacterial community composition. Areas rich in POM may select for particle-associated bacterial species with specialized extracellular enzymes (Chróst 1991) and high cell-specific growth rates that have been shown to correlate with changes in bacterial community composition during an algal bloom (Fandino et al. 2001). The decreased richness we observed at high POM stations may therefore have been due to changes in the freeliving assemblage, since particle-associated bacteria probably comprised a smaller fraction of the total sample (ca. $20 \%$; Yager et al. 2001).

Alternatively, the viral impact may differ in the 2 environments. Viral lysis of nonresistant bacteria at high POM stations in this study could be responsible for the observed shifts in bacterial community composition, as seen by the reduction in free-living species richness during high POM conditions. Lytic infection by virioplankton can also lead to changes in bacterial community composition (Fuhrman \& Schwalbach 2003, Middelboe et al. 2003), especially when VB reaches a 'lytic infection threshold' of $10^{12} \mathrm{ml}^{-1}$ (Wilcox \& Fuhrman 1994), as found in high POM stations in this study. We observed a negative correlation between VB and the number of free-living bands. Lysis of bacterial hosts can release DOM, which can stimulate bacterial growth (Noble et al. 1999), explaining the positive correlation between bacterial abundance and VLP (Bratbak et al. 1990, Middelboe et al. 2003). The high correlation between VLP and MDS distance, however, suggests that only part of the community was stimulated and some succession occurred. Dominant, nonresistant species are more likely to be infected and lysed (Fuhrman \& Suttle 1993) because virioplankton are density-dependent (Wiggins \& Alexander 1985, Wilcox \& Fuhrman 1994) and highly genus- and species- specific (Ackermann \& DuBow 1987). Lysis-induced DOM release may therefore stimulate the growth of resistant bacterial strains (Middelboe et al. 2003) leading to changes in bacterial community composition. Clonal diversity is shown to shift from phage-sensitive to phage-resistant clones in cultured phage-host systems (Middelboe et al. 2001). Viruses may therefore reduce the abundance of nonresistant bacteria while increasing the abundance of resistant bacteria, thus changing species composition.

We speculate that the presence of POM may select for fast-growing particle-associated bacteria with cellsurface enzymes (Chróst 1991) that are susceptible to viral recognition. Although there is no evidence yet that viruses impact particle-associated bacteria to a greater extent than free-living bacteria (Simon et al. 2002), we might expect that viruses are more likely to encounter their hosts on 2-dimensional particle surfaces than in the water column (Jumars 1993). Since infection can be density-dependent (Wiggins \& Alexander 1985, Wilcox \& Fuhrman 1994), the hypothetical lytic threshold may be reached at the microscale. Viral lysis of nonresistant particle-associated species may initiate differences by producing DOM in close proximity to resistant particle-associated bacteria. This effect may be overlooked in large sample volumes.

Other hypotheses for the observed variation in species richness include links between bacterial diversity and algal diversity (Pinhassi et al. 2004). We were unable to make measurements on the nature of the phytoplankton community during this opportunistic cruise, but the area is typically dominated by centric diatoms (genera Chaetoceros and Thalassiosira) during August (Booth \& Horner 1997), with decreasing contributions of autotrophic flagellates as water moves north off the shelf. Certainly, a variable contribution of ice algal material sloughing off the melting ice into the water column could have influenced both algal and bacterial community structure (although ice algae are uncommon this late in the summer and were not observed to be significant). A more uniform composition of DOC during algal blooms might have also lead to a decreased richness of free-living bacteria. A methodological constraint could be that increased DNA content of a few species during the bloom may have lowered the resolution of the DGGE method (although we believe the dynamic range of DGGE is large enough not to be a problem). Finally, the Chukchi Sea is a region where several water masses are mixed together (Weingartner et al. 1998). While the correlations are robust, causality due to a bloom progression is mostly speculation; our sampled variation could simply have been due to horizontal heterogeneity (e.g. Yannarell et al. 2005). 


\section{Relevance of results to high-latitude carbon cycling}

Polar oceans account for approximately 10 to $20 \%$ of the global oceanic carbon production (Behrenfeld \& Falkowski 1997) and have elevated $f$ (new:total production) and e (export:total production) ratios compared to temperate and tropical latitudes; this effect is thought to be due to the combination of low temperature and high production (Laws et al. 2000). In an environment characterized by strong localized pulses of primary production, the response of microorganisms within the euphotic zone may determine the rate of carbon, nitrogen, and phosphate remineralization and also the fraction of total production that is exported from that zone (Wiebe \& Pomeroy 1991). High bacterial growth rates (Rivkin et al. 1996, Rich et al. 1997) and a dynamic bacterial community composition (Yager et al. 2001) that differs between free-living and whole communities suggests that cold-adapted, particle-associated bacteria may be important in determining this high export fraction.

Settling POM in Arctic seas provides a source of food for benthic communities (Ambrose \& Renaud 1995) and a means of sequestering carbon within the deep ocean. The efficiency of this biological pump, or the degree to which particles are remineralized along the way, depends largely on the activities and composition of microorganisms responsible for solubilizing the organic matter to a form that can be incorporated and then respired. Understanding the processes that transform particulate material, especially the degradation and remineralization of particles, is important in understanding this critical global flux. Azam and coworkers have long argued for a link between the scales of bacteria and larger issues such as particle flux and climate change (e.g. Azam \& Long 2001). Marine studies that determine microbial abundance, activity and community composition of free-living and particleassociated bacteria are therefore necessary to determine the efficiency of carbon sequestration in the ocean and its effects on the global carbon cycle.

\section{CONCLUSIONS}

Algal blooms in the summertime Chukchi Sea in 2000 were characterized by increased microbial abundance, decreased species richness, and decreased similarity between free-living and whole community bacterial assemblages. Bacterial and viral abundance correlated positively with a bloom index identified by PCA that included POC, PON, TOC and chl a (but not DOC or nutrients), but species richness and similarity were significantly reduced at the high POM stations. Algal blooms may therefore increase microbial abun- dance while stimulating a succession of the bacterial assemblage to fewer free-living species and more specialized particle-associated bacteria. Our data suggest that the mechanism for this succession could be increased viral lysis.

Acknowledgements. This research was supported by a UGA Marine Science Department graduate teaching assistantship to L.R.H.; a UGA Faculty Research Grant to P.L.Y. and an NSF/SCICEX award OPP 98-09971 to J.T.H. We thank the following scientists from AWS00 for providing data for this study: G. Cota (chl a; Old Dominion University), L. Belicka and H. R. Harvey (POM; UMCES-CBL), and A. Skoog (DOC; University of Connecticut). We also thank the following scientists for their assistance in sample analysis: R. Lee (DIN; UGA), E. J. Biers (PCR/DGGE; UGA) and K. E. Wommack (VLP; University of Delaware). We thank S. Holland for assistance with statistical analyses. Special thanks to AWS00 Chief Scientist, the late G. F. Cota who will be missed by all, and USCGC Polar Star Captain Garrett and crew members for their excellent technical support. The manuscript was greatly improved by the comments of 3 anonymous reviewers.

\section{LITERATURE CITED}

Acinas SG, Anton J, Rodriguez-Valera F (1999) Diversity of free-living and attached bacteria in offshore western Mediterranean waters as depicted by analysis of genes encoding 16S rRNA. Appl Environ Microbiol 65:514-522

Ackermann, HW, DuBow MS (1987) Viruses of prokaryotes. Vol 1. General properties of bacteriophages. CRC Press, Boca Raton, FL

Ambrose WG Jr, Renaud PE (1995) Patterns of sediment carbon and biomass in the Northeast Water polynya: evidence of benthic-pelagic coupling. J Geophys Res 100:4411-4421

Azam F, Long RA (2001) Oceanography: sea snow microcosms. Nature 414:497-498

Bano N, Hollibaugh JT (2000) Diversity and distribution of DNA sequences with affinity to ammonia-oxidizing bacteria of the $\beta$ subdivision of the class Proteobacteria in the Arctic Ocean. Appl Environ Microbiol 66:1960-1969

Bano N, Hollibaugh JT (2002) Phylogenetic composition of bacterioplankton assemblages from the Arctic Ocean. Appl Environ Microbiol 68:505-518

Becquevort S, Rousseau V, Lancelot C (1998) Major and comparable roles for free-living and attached bacteria in the degradation of Phaeocystis-derived organic matter in Belgian coastal waters of the North Sea. Aquat Microb Ecol 14:39-48

Behrenfeld MJ, Falkowski PG (1997) Photosynthetic rates derived from satellite-based chlorophyll concentration. Limnol Oceanogr 42:1-20

Belicka LL (2002) Biochemical markers of carbon source and transport in the western Arctic Ocean. MS thesis, University of Maryland, College Park, MD

Booth BC, Horner RA (1997) Microalgae on the Arctic Ocean Section, 1994: species abundance and biomass. Deep-Sea Res II 44(8):1607-1622

Bratbak G, Heldal M, Norland S, Thingstad TF (1990) Viruses as partners in spring bloom microbial trophodynamics. Appl Environ Microbiol 56:1400-1405

Carlson CA, Ducklow HW (1996) Growth of bacterioplankton and consumption of dissolved organic carbon in the Sargasso Sea. Aquat Microb Ecol 10:69-85 
Castberg T, Larsen A, Sandaa RA, Brussaard CPD and 5 others G (2001) Microbial population dynamics and diversity during a bloom of the marine coccolithophorid Emiliana huxleyi (Haptophyta). Mar Ecol Prog Ser 221:39-46

Chen F, Lu JR, Binder BJ, Liu YC, Hodson RE (2001) Application of digital analysis and flow cytometry to enumerate marine viruses stained with SYBR gold. Appl Environ Microbiol 67:539-545

Chróst RJ (1991) Environmental control of the synthesis and activity of aquatic microbial ectoenzymes. In: Chróst RJ (ed): Microbial enzymes in aquatic environments. Springer-Verlag, New York, p 22-59

Cochlan WP, Wikner J, Steward GF, Smith DC, Azam F (1993) Spatial distribution of viruses, bacteria, and chlorophyll a in neritic, oceanic, and estuarine environments. Mar Ecol Prog Ser 92:77-87

Cole JJ, Pace ML, Findlay S (1988) Bacterial production in fresh and saltwater ecosystems: a cross-system overview. Mar Ecol Prog Ser 43:1-10

Cota GF, Pomeroy LR, Harrison WG, Jones EP, Peters F, Sheldon WM, Weingartner TR (1996) Nutrients, primary production and microbial heterotrophy in the southeastern Chukchi Sea: Arctic summer nutrient depletion and heterotrophy. Mar Ecol Prog Ser 135:247-258

Crump BC, Baross JA, Simenstad CA (1998) Dominance of particle-attached bacteria in the Columbia River estuary, USA. Aquat Microb Ecol 14:7-18

Crump BC, Armbrust EV, Baross JA (1999) Phylogenetic analysis of particle-attached and free-living bacterial communities in the Columbia River, its estuary, and the adjacent coastal ocean. Appl Environ Microbiol 65:3192-3204

Davis JC (2002) Statistics and data analysis in geology, 3rd edn. John Wiley \& Sons, New York

Delong EF, Franks DG, Alldredge AL (1993) Phylogenetic diversity of aggregate-attached vs free-living marine bacterial assemblages. Limnol Oceanogr 38:924-934

Fandino LB, Riemann L, Steward GF, Long RA, Azam F (2001) Variations in bacterial community structure during a dinoflagellate bloom analyzed by DGGE and 16S rDNA sequencing. Aquat Microb Ecol 23:119-130

Ferrari VC, Hollibaugh JT (1999) Distribution of microbial assemblages in the Central Arctic Ocean Basin studied by PCR/DGGE: analysis of a large data set. Hydrobiologia 401:55-68

Fuhrman JA (1999) Marine viruses and their biogeochemical and ecological effects. Nature 399:541-548

Fuhrman JA, Schwalbach M (2003) Viral influence on aquatic bacterial communities. Biol Bull (Woods Hole) 204: 192-195

Fuhrman JA, Suttle CA (1993) Viruses in marine planktonic systems. Oceanography 6:50-62

Guo L, Tanaka T, Wang D, Tanaka N, Murata A (2004) Distributions, speciation and stable isotope composition of organic matter in the southeastern Bering Sea. Mar Chem 91:211-226

Hagström Å, Pinhassi J, Zweifel UL (2001) Marine bacterioplankton show bursts of rapid growth induced by substrate shifts. Aquat Microb Ecol 24:109-115

Hennes KP, Simon M (1995) Significance of bacteriophages for controlling bacterioplankton growth in a mesotrophic lake. Appl Environ Microbiol 61(1):333-340

Hollibaugh JT, Wong PS, Murrell MC (2000) Similarity of particle-associated and free-living bacterial communities in northern San Francisco Bay, California. Aquat Microb Ecol 21:103-114

Holm-Hansen O, Lorenzen CJ, Holmes RW, Strickland JDH (1965) Fluorometric determination of chlorophyll. J Cons
Perm Int Explor Mer 30:3-15

Huston AL, Deming JW (2002) Relationships between microbial extracellular enzymatic activity and suspended and sinking particulate organic matter: seasonal transformations in the North Water. Deep-Sea Res II 49:5211-5225

Jakobsson M, Cherkis NZ, Woodward J, Macnab R, Coakley B (2000) New grid of Arctic bathymetry aids scientists and mapmakers. EOS Trans Am Geophys Un 81(9):89, 93, 96

Jumars, PA (1993) Concepts in biological oceanography: an interdisciplinary primer. Oxford University Press, New York

Jumars PA, Penry DA, Baross JA, Perry MJ, Frost BW (1989) Closing the microbial loop: dissolved carbon pathways to heterotrophic bacteria from incomplete ingestion, digestion and absorption in animals. Deep-Sea Res 36:483-495

Kimura H, Sato M, Sugiyama C, Naganuma T (2001) Coupling of thraustochytrids and POM, and of bacterio- and phytoplankton in a semi-enclosed coastal area: implication for different substrate preferences by the planktonic decomposers. Aquat Microb Ecol 25:293-300

Laws EA, Falkowski PG, Smith WO, Ducklow H, McCarthy JJ (2000) Temperature effects on export production in the open ocean. Global Biogeochem Cycles 14:1231-1246

Lee CW, Kudo I, Yanada M, Maita Y (2001) Bacterial abundance and production and heterotrophic nanoflagellate abundance in subarctic coastal waters (Western North Pacific Ocean). Aquat Microb Ecol 23:263-271

Long RA, Azam F (2001) Antagonistic interactions among marine pelagic bacteria. Appl Environ Microbiol 67: 4975-4983

Maranger R, Bird DF, Juniper SK (1994) Viral and bacterial dynamics in Arctic sea-ice during the spring algal bloom near Resolute Passage, NWT, Canada. Mar Ecol Prog Ser 111:121-127

Maranger R, Bird DF (1995) Viral abundance of aquatic systems - a comparison between marine and fresh-waters. Mar Ecol Prog Ser 121:217-226

McCune B, Mefford MJ (1999) PC-ORD. Multivariate analysis of ecological data, Version 4.0. MjM Software Design, Gleneden Beach, OR

Middelboe M, Hagström $\AA$, Blackburn N, Sinn B and 5 others (2001) Effects of bacteriophages on the population dynamics of four strains of pelagic bacteria. Microb Ecol 42: 395-406

Middelboe M, Neilsen TG, Bjornsen PK (2002) Viral and bacterial production in the North Water: in situ measurements, batch-culture experiments and characterization and distribution of a virus-host system. Deep-Sea Res II 49:5063-5079

Middelboe M, Riemann L, Steward GF, Hansen V, Nybroe O (2003) Virus-induced transfer of organic carbon between marine bacteria in a model community. Aquat Microb Ecol 33:1-10

Murray AE, Hollibaugh JT, Orrego C (1996) Phylogenetic compositions of bacterioplankton from two California estuaries compared by denaturing gradient gel electrophoresis of 16S rDNA fragments. Appl Environ Microbiol 62:2676-2680

Muyzer G, de Waal EC, Uitterlinden AG (1993) Profiling of complex microbial populations by denaturing gradient gel electrophoresis analysis of polymerase chain reactionamplified genes coding for 16S rRNA. Appl Environ Microbiol 59:695-700

Noble RT, Fuhrman JA (2000) Rapid virus production and removal as measured with fluorescently labeled viruses as tracers. Appl Environ Microbiol 66:3790-3797

Noble RT, Middelboe M, Fuhrman JA (1999) Effects of viral 
enrichment on the mortality and growth of heterotrophic bacterioplankton. Aquat Microb Ecol 18:1-13

Paul JH, Myers B (1982) Fluorometric determination of DNA in aquatic microorganisms by use of Hoechst 33258. Appl Environ Microbiol 43:1393-1399

Pinhassi J, Hagström Å (2000) Seasonal succession in marine bacterioplankton. Aquat Microb Ecol 21:245-256

Pinhassi J, Sala MM, Havskum H, Peters F, Guadayol O, Malits A, Marrase C (2004) Changes in bacterioplankton composition under different phytoplankton regimens. Appl Environ Microbiol 70(11):6753-6766

Poremba K, Tillmann U, Hesse KJ (1999) Distribution of bacterioplankton and chlorophyll-a in the German Wadden Sea. Helgol Mar Res 53:28-35

Porter KG, Feig YS (1980) The use of DAPI for identifying and counting aquatic microflora. Limnol Oceanogr 25:943-948

Rich J, Gosselin M, Sherr EB, Sherr BF, Kirchman DL (1997) High bacterial production, uptake and concentrations of dissolved organic matter in the Central Arctic Ocean. Deep-Sea Res II 44:1645-1663

Riemann L, Winding A (2001) Community dynamics of freeliving and particle-associated bacterial assemblages during a freshwater phytoplankton bloom. Microb Ecol 42: $274-285$

Riemann L, Steward GF, Azam F (2000) Dynamics of bacterial community composition and activity during a mesocosm experiment. Appl Environ Microbiol 66:578-587

Ritzrau W (1997) Pelagic microbial activity in the Northeast Water Polynya, summer 1992. Polar Biol 17:259-267

Rivkin RB, Anderson MR, Lajzerowicz C (1996) Microbial processes in cold oceans: relationship between temperature and bacterial growth rate. Aquat Microb Ecol 10:243-254

Simon M, Grossart HP, Schweitzer B, Ploug H (2002) Microbial ecology of organic aggregates in aquatic ecosystems. Mar Ecol Prog Ser 28:175-211

Skoog A, Thomas D, Lara R, Richter K (1997) Methodological investigations on DOC determinations by the HTCO method. Mar Chem 56:39-44

Smith DC, Simon M, Aldredge AL, Azam F (1992) Intense hydrolytic enzyme activity on marine aggregates and implication for rapid dissolution. Nature 359:139-142

Sokal RR, Rohlf FJ (1995) Biometry. The principles and practice of statistics in biological research, 3rd edn. WH Freeman \& Co, New York

Solórzano L (1969) Determination of ammonia in natural waters by the phenol hypochlorite method. Limnol Oceanogr 14:799-801

Steward GF, Smith DC, Azam F (1996) Abundance and production of bacteria and viruses in the Bering and Chukchi Seas. Mar Ecol Prog Ser 131:287-300

Strickland JDH, Parsons TR (1972) A practical handbook of seawater analysis. 2nd edn. Bull Fish Board Can 167

Editorial responsibility: Fereidoun Rassoulzadegan, Villefranche-sur-Mer, France
Turley CM, Stutt ED (2000) Depth-related cell-specific bacterial leucine incorporation rates on particles and its biogeochemical significance in the Northwest Mediterranean. Limnol Oceanogr 45:419-425

Vetter YA, Deming JW (1994) Extracellular enzyme activity in the Arctic Northeast Water Polynya. Mar Ecol Prog Ser 114:23-34

Vetter YA, Deming JW, Jumars PA, Krieger-Brockett BB (1998) A predictive model of bacterial foraging by means of freely released extracellular enzymes. Microb Ecol 36: 75-92

Wang J, Cota GF, Ruble DA (2005) Absorption and backscattering in the Beaufort and Chukchi Seas. J Geophys Res 110. C04014, doi: 10.1029/2002JC001653

Weingartner T, Cavalieri DJ, Aagaard K, Sasaki Y (1998) Circulation, dense water formation, and outflow on the northeast Chukchi Shelf. J Geophys Res 103:7647-7661

Wells LE, Deming JW (2003) Abundance of bacteria, the cytophaga-flavobacterium cluster and Archaea in cold oligotrophic waters and nepheloid layers of the Northwest Passage, Canadian Archepelago. Aquat Microb Ecol 31: 19-31

Wheeler PA, Gosselin M, Sherr EB, Thibault D, Kirchman DL, Benner R, Whitledge TE (1996) Active cycling of organic carbon in the central Arctic Ocean. Nature 380:697-699

Wiebe WJ, Pomeroy LR (1991) Possible effects of global warming on marine food webs at low temperature. In: Dudley EC (ed) The unity of evolutionary biology. Proceedings of the 4th International Congress of Systematic and Evolutionary Biology. Dioscorides Press, Portland, OR, p 179-183

Wiggins BA, Alexander M (1985) Minimum bacterial density for bacteriophages replication: implications for significance of bacteriophages in natural ecosystems. Appl Environ Microbiol 49:19-23

Wilcox RM, Fuhrman JA (1994) Bacterial viruses in coastal seawater: lytic rather than lysogenic production. Mar Ecol Prog Ser 114:35-45

Wommack KE, Hill RT, Kessel M, Russek-Cohen E, Colwell RR (1992) Distribution of viruses in the Chesapeake Bay. Appl Environ Microbiol 58:2965-2970

Yager PL, Deming JW (1999) Pelagic microbial activity in an Arctic polynya: testing for temperature and substrate interactions using a kinetic approach. Limnol Oceanogr 44:1882-1893

Yager PL, Connelly TL, Mortazavi B, Wommack KE, Bano N, Bauer JE, Opsahl S, Hollibaugh JT (2001) Dynamic bacterial and viral response to an algal bloom at subzero temperatures. Limnol Oceanogr 46:790-801

Yannarell AC, Triplett EW (2005) Geographic and environmental sources of variation in lake bacterial community composition. Appl Environ Microbiol 71(1):227-239

Submitted: February 2, 2005; Accepted: May 9, 2005

Proofs received from author(s): August 5, 2005 